\title{
21. Tiyatro ve psikolojik gerçekçilik: “Kafana Tiyatro” (In-Yer-Head Theatre)
}

\section{Gamze ŞENTÜRK*}

APA: Şentürk, G. (2021) Tiyatro ve psikolojik gerçekçilik: "Kafana Tiyatro" (In-Yer-Head Theatre) RumeliDE Dil ve Edebiyat Araştırmaları Dergisi, (Ö9), 246-260. DOI: 10.29000/rumelide.983506.

\section{Öz}

Küçücük bir beden içine hapsolan insan için, yaşadığı dünya bir yandan sürprizlere gebe hoş bir yer bir yandan da içinde gizem ve korku yüklü büyük, tehlikeli ve kaotik bir yerdir. İçinde paradokslar barındıran dünyada yaşam serüvenine başlayan insanın hayatını devam ettirmesi hiç de kolay değildir. İnsan hem dünyadaki her türlü dış etmene hem de bu dış etmenlerin iç dünyasında yarattığı psikolojik faktörlere karşı mücadele etmek zorunda bırakılmıştır. İnsan için yaşam dış dünya ve iç dünya arasında denge kurmakla rayında devam edebilir gibi görünmekte iken her insanın kişisel özelliklerinin farklı olması nedeniyle durum karmaşık bir hal almaktadır. Bu noktada dıș dünyadan gelen her türlü tehlikeye karşı insanın yapması gereken ise hem beden sağlığını hem de ruh sağlığını korumaktır. Bu korunmayı sağlayan insan için hayat serüveni biraz daha seyrinde devam edecekken aynı korunmayı sağlayamayan veya dış dünyadan gelen tehlikelere karşı kendini koruyamayacak kadar güçsüz kalanlar için hayat daha da zorlaşmaktadır. Dış bir gerçekliğe sahip insanın tüm yaşananlar karşısında ürettiği iç gerçekliği de edebiyatın ve tiyatronun temel konularından biridir. Bu noktada tiyatroda travma, melankoli, histeri ve nostalji gibi insanın iç gerçekliği veya bilinçdışı ile ilintili tatsız anlatılar üretilmiştir ve üretilmeye de devam etmektedir. Sorbonne Üniversitesi öğretim üyelerinden Solange Ayache, 2017'de yaptığı “'In-YerHead' Theatre: Staging the Mind in Contemporary British Drama Towards a Quantum Psychopoetics of the Stage” başlıklı doktora tez çalışmasında 2000’li yıllarda İngiliz tiyatrosunda ön plana çıkan bu tatsız anlatıları, Aleks Sierz'in 'Suratına Tiyatro' (In-Yer-Face Theatre) kavramına gönderme yaparak 'Kafana Tiyatro' (In-Yer-Head Theatre) veya “Akıl Uzamı Tiyatrosu' (Theatre of Mental Space) örnekleri olarak tanımlamaktadır. Bu çalışma, psikolojik gerçekçilik ve travma konularını merkeze koyarak 'Kafana Tiyatro' kavramını açıklamayı ve İngiliz tiyatrosunun deneysel ve yenilikçi oyun yazarlarından Sarah Kane (1971-1999), Sarah Daniels (1956-) ve Anthony Neilson'dan (1967-) seçilmiş örnek oyunlar üzerinden travma temelli tatsız anlatıları örneklendirmeyi amaçlamaktadır.

Anahtar kelimeler: Tiyatro, psikolojik gerçeklik, Kafana Tiyatro, travma

\section{Theatre and psychological realism: "In-Yer-Head Theatre"}

\begin{abstract}
For human trapped in a tiny body, on the one hand the world s/he lives in is a pleasant place with surprises, but on the other hand it is a big, dangerous and chaotic place full of mystery and fear. It is not easy for person who has started his/her life adventure in the world with paradoxes to continue his/her life. S/he has been forced to struggle against both all kinds of external factors in the world and the psychological factors created by these external factors in his/her inner world. While life seems to be able to continue on its way by establishing a balance between the outer world and the inner world, the situation becomes complicated because the personal characteristics of each person are different. At this
\end{abstract}

Dr. Öğr. Üyesi, Munzur Üniversitesi, Edebiyat Fakültesi, Batı Dilleri ve Edebiyatları Bölümü; (Tunceli, Türkiye) gamzesenturk_26_01@hotmail.com, ORCID ID: 0000-0002-5097-7739. [Araştırma makalesi, Makale kayıt tarihi: 10.07.2021kabul tarihi: 20.08.2021; DOI: 10.29000/rumelide.983506]

Adres Address

RumeliDE Dil ve Edebiyat Araştırmaları Dergisi Osmanağa Mahallesi, Mürver Çiçeği Sokak, No:14/8 Kadıköy - ISTANBUL / TÜRKIYE 34714 e-posta: editor@rumelide.com tel: +90 $5057958124,+902167730616$

RumeliDE Journal of Language and Literature Studies Osmanağa Mahallesi, Mürver Çiçeği Sokak, No:14/8

Kadıköy - ISTANBUL / TURKEY 34714

e-mail: editor@rumelide.com

phone: +90 5057958124 , +90 2167730616 
point, what one should do against all kinds of dangers from the outside world is to protect both his/her physical and mental health. While the adventure of life will continue for the person who provides this protection, the life becomes more difficult for those who cannot provide the same protection or who are too weak to protect themselves against the dangers from the outside world. The inner reality that a person with an external reality produces in the face of all experiences is one of the main subjects of literature and theatre. At this point, unpleasant narratives related to the inner reality or unconscious of the human being such as trauma, melancholy, hysteria and nostalgia have been produced and continue to be produced. Solange Ayache, Sorbonne University faculty member, in her doctoral thesis titled "InYer-Head' Theatre: Staging the Mind in Contemporary British Drama Towards a Quantum Psychopoetics of the Stage" (2017), defines these unpleasant narratives which became prominent in British theatre in the 2000s as 'In-Yer-Head Theatre' or 'Theatre of Mental Space', referring to Aleks Sierz's concept of 'InYer-Face Theatre'. This study aims to explain the concept of 'In-Yer-Head Theatre' by putting psychological realism and trauma in the center, and to exemplify unpleasant trauma-based narratives through plays chosen from experimental and innovative playwrights of British theatre such as Sarah Kane (1971-1999), Sarah Daniels (1956-), and Anthony Neilson (1967-).

Keywords: Theatre, Psychological Realism, In-Yer-Head Theatre, Trauma

\section{Giriş}

On dokuzuncu yüzyılın ortalarında toplumsal ve kültürel koșulları yansıtmak amacıyla Fransa'da gelişen gerçekçilik, bir diğer adıyla realizm akımı, literatürde farklı şekillerde tezahür etmiştir. Bu noktada gerçekçilik akımını klâsik gerçekçilik, doğalcılık, fotoğraf gerçekçiliği, politik gerçekçilik, toplumsal gerçekçilik, büyülü gerçekçilik ve tarihsel gerçekçilik şeklinde farklı başlıklar altında ele almak mümkündür. Gerçekçiliğin bu temsilleri yanında yirminci yüzyılda Psikanaliz kuramının gelişimiyle birlikte edebiyatta kendini gösteren bir gerçekçilik türü de psikolojik gerçekçiliktir. Edebi eserlerde karakterlerin iç dünyalarını açı̆̆a çıkarmaya yönelen bu gerçekçilik türü, söz konusu dönemde ilk olarak kendini roman çalışmalarında göstermiş olup psikolojik gerçekçilik dikkate alınarak yazılan romanlar da 'psikolojik roman' veya 'ruhbilimsel roman' diye nitelendirilmiştir. Eleştirmen ve çevirmen Gürsel Aytaç Genel Edebiyat Bilimi (1999) başlıklı çalışmasında, psikolojik romanı "olayları, kişilerin ruh hayatının gözlem, analiz ve yorumuna dayanarak geliştiren, bu nedenle daha çok ruh manzaraları veren roman çeşidi” (s.160) olarak tanımlamış ve "Freud'un rüya ve bilinçaltı konularındaki keşiflerini, ruh analizleri ve yorumlarını esas ilke olarak kullanan roman türü”nü de (s.160) 'psikanalitik roman' şeklinde nitelendirmiştir. Bu tür romanlar özellikle bilinç akışı tekniğini, iç monologları ve geriye dönüşleri kullanarak karakterlerin öznel gerçekliklerini okura sunmayı amaçlamıştır.

İngiliz yazar J. A. Cuddon, A Dictionary of Literary Terms and Literary Theory (1977) başlıklı çalışmasında psikolojik gerçekçiliği şöyle açıklar:

Gerçekçilik, başka bir önemli bağlamda, yani psikolojik gerçekçilikte ortaya çıkar. Bu, zihnin iç işleyişini, düşünce ve duygu analizini, kişiliğin ve karakterin doğasının sunumunu tasvir etmede gerçeğe bağlılı̆̆ ifade eder. Bu gerçekçilik, karakterine uygun davranacak kurgusal bir karakteri gerektirir. Psikolojik gerçekçilikte son nokta, (dilediğiniz kadar) bilinç akışı yönteminin kullanılmasıdır. Bu tür gerçekçilik de yazarlar bilinç ve bilinçaltı bölgelerin skatolojik (yani açık saçık veya müstehcen) ve örektik (yani duygulanımsal ve hazsal) kaosunun derinine ve ötesine büyük bir zevkle indikçe genellikle (diledikleri kadar) bir tür çöküşle sonuçlanmıştır. (1991, s.777).

Buradan da anlaşıldığı üzere yaşamı olduğu gibi tasvir eden gerçekçilik, karakterlerin içsel yaşantısına odaklanıp onların zihinsel süreçlerini ortaya koyduğunda psikolojik gerçekçilik olarak kendini gösterir.

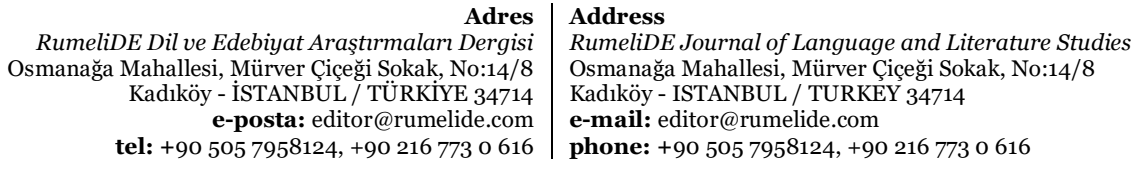


Psikolojik gerçekçilik eserlerde karakterin duygu, düşünce ve hislerinin detaylı bir şekilde açılanmasını ifade eder. Bir anlamda psikolojik gerçekçilik, "bireysel yaşamların yoğun bir şekilde özgönderimsel ve itirafa dayalı açıklamalarıyla karakterize edi[len]" (Long \& Jean So, 2016, s.358) bir tür olarak literatürdeki yerini almıştır. İnsan ruhunun derinliklerindeki korkularını, endişelerini ve hayal kırıklıklarını gerçekçi bir açıdan ortaya döken psikolojik gerçekçilik, psikanalitik temellere dayalı analizler yapmayı mümkün kılmaktadır. Çevre ve olayların etkilerinin karakterlerin psikolojilerinde yarattığı iç çatışmalar, böylelikle psikanalitik bir bakış açısından ele alınmış olur.

Amerikalı romancı Henry James (1843-1916), edebiyatta psikolojik gerçekçiliği uygulayan ilk isim olarak akla gelir. James, Amerikan gerçekçiliğinin ve psikolojik gerçekçiliğin babası olarak kabul edilir. Yazar çalışmalarında, sosyal ve ahlaki problemlerle boğuşan karakterlerin yaşadıkları dünya ve içinde yer aldıkları toplumsal yapıdan kaynaklı iç çatışmalarını ortaya döker (Ross, 2003, s.939). The American (1877), Daisy Miller (1878), The Portrait of a Lady (1881) ve The Ambassadors (1903) gibi önde gelen çalışmalarında James, psikolojik gerçekçilik yoluyla karakterlerinin iç dünyalarını çeşitli stratejilerle okurlarıyla paylaşır. Aynı zamanda Jacob's Room (1922), Mrs. Dalloway (1925), To the Lighthouse (1927), The Waves (1931) ve Between the Acts (1941) gibi eserleriyle bilinen İngiliz yazar Virginia Woolf (1882-1941); The Sound and the Fury (1929), As I Lay Dying (1930) ve Absalom, Absalom! (1936) gibi eserleri ile bilinen Amerikalı yazar William Faulkner (1892-1967); The Great Gatsby (1925) başlıklı romanıyla ünlenmiş İrlanda asıllı Amerikalı yazar F. Scott Fitzgerald (1896-1940); The Red Badge of Courage (1895) başlıklı romanıyla ünlenmiş Amerikalı yazar Stephen Crane (1871-1900); Ulysses (1922) başlıklı romanıyla tanınmış İrlandalı yazar James Joyce (1882-1941); Sons and Lovers (1913) ve Woman in Love (1920) gibi eserleri ile bilinen İngiliz yazar D. H. Lawrence (1885-1930); Pamela (1740) başlıklı eseriyle Samuel Richardson (1989-1761), The Wasteland (1922) başlıklı şiiriyle bilinen Amerika doğumlu İngiliz yazar T. S. Eliot (1888-1965) ve The Age of Innocence (1920) adlı romanıla tanınan Edith Wharton (1862-1937) gibi isimler psikolojik gerçekçiliği çalışmalarında kullanan yazarlar arasında yerlerini alır. Bu noktada bir diğer önemli isim ise Rus roman yazarı Fyodor M. Dostoyevski'dir (1821-1881). Dostoyevski "bana psikolog diyorlar: Yanıllyorlar. Ben daha yüce bir manada oldukça realistim, yani insan ruhunun tüm derinliklerini gösteririm," (akt. Wellek, 2005, s.312) diyerek eserlerini üretirken psikolojik gerçekçilikten yararlandığını ortaya koyar. Adı zikredilen yazarlar bahsi geçen çalışmaları başta olmak üzere eserlerinde karakterlerinin iç dünyalarını, olaylar karşısında hissettiklerini, ruhsal durumlarını ve iç tepkilerini bilinç akışı, iç monologlar, geriye dönüşler ve olayları birinci kişinin ağzından anlatma gibi yöntemlere başvurarak ortaya koymuşlardır. Psikolojik gerçekçilik doğrultusunda üretilmiş olan bu çalışmalar, karakterlerin psikolojilerini derinlemesine analiz etmektedir. Bir başka ifadeyle, bu eserlerde okurlar karakterlerin korkuları, kaygıları, iç çatışmaları ile karakterlerle birlikte yüzleşmektedirler. Birey ve bireyin iç dünyasına odaklanan bu eserler, "karakterlerin eylemlerini açıklamak için onların motivasyonlarını ve içsel düşüncelerini yazan, son derece karakter odaklı bir kurgu türü" (Kennedy, 2019) olarak ortaya çıkan psikolojik gerçekçi edebiyatın seçkin birer örneği olarak karşımıza çıkarlar.

"Psikoloji ve edebiyatın kesiştiği noktada ortaya çıkan ve kişilerin ruhî durumlarını ayrıntılarıyla tahlil etmesi bakımından diğer roman türlerinden ayrılan psikolojik roman" (Ayata \& Tonga, 2008, s.19) türünün yanında, psikolojik gerçekçilik tiyatroda da kullanılmaktadır. Oyun yazarları karakterlerin iç dünyalarının yansıtılmasında iç monolog, akıl uzamının temsil edilmesi, hayali karakterler ve gerçeküstü temsiller gibi yöntemler kullanarak bir psikolojik gerçekçilik ortaya koyarlar. Karakterlerin içsel motivasyonlarını açığa çıkaran psikolojik gerçekçilik, Eugene O”Neill (1888-1953), Tennessee Williams (1911-1983), Arthur Miller (1915-2005), Peter Shaffer (1926-2006), Samuel Beckett (1906-1989), August Strindberg (1849-1912) ve Henrik Ibsen (1828-1906) gibi oyun yazarlarının öncülüğünde tiyatroda gelişme göstermiştir. Adı geçen oyun yazarları, gerçek yaşamda insan eylemlerinin karmaşı motivasyonlardan kaynaklandığı 
düşüncesinden hareketle karakterlerinin davranışlarının altında yatan içsel gerçekliklerini oyunlarında yansıtmışlardır. Karakter temelli bir amaç çerçevesinde ilerleyen oyunlarında yansıttıkları içsel gerçeklik, seyircinin yaşadığı dünyayı ana karakterin öznel bakış açısıyla anlamasına izin vermektedir. Tiyatroda psikolojik gerçekliğin ele alındığı uzam ise akıl veya zihin uzamı olarak isimlendirilmektedir ki bu uzam "karakterlerin fantezi üretiminin dramanın gerçeği haline geldiği bir uzam" (Borgstorm, 1998, s.vii) olarak karşımıza çıkar. Bu uzamda karakterlerin içsel yaşantılarını oluşturan dürtüleri, hayal kırıklıkları, korkuları, endişeleri, tepkileri ve ikilemleri herhangi bir sansüre uğramaksızın tüm gerçekliğiyle sergilenir.

İngiliz tiyatro profesörü Elaine Aston, gerçekçiliğinin yirmi birinci yüzyıl oyunlarında tekrar ele alındığının ve bu bağlamda geleneksel estetik anlayışın yerini oldukça farklı, heterojen ve radikal bir estetik anlayış aldığını belirtir. Aston’a göre, özellikle yirminci yüzyılın sonlarına doğru çıplak ya da doğalcı (natüralist) gerçekçi geleneğin, yani pür dış gerçekliğin temsilinin boğucu/sıkıcı olduğunun düşünülmesi ardından yeni oyun yazarları tarafından sahnede gerçekliği sunmanın farklı yolları aranmıştır (2016, s.17). Bu noktada adeta "yeni yazının kutsal kabı artık dilde, içerikte ve biçimde çağdaş olan ve kışkırtıcı olan"ı (Sierz, 2011, s.68) temsil etmektedir. Bu, tiyatronun sahnede içsel gerçekliği kucaklaması anlamını taşır. Benzer bir biçimde Aston gibi Aleks Sierz de Rewriting the Nation: British Theatre Today (2011) başlıklı çalışmasının yedinci bölümünde 2000'li yıllarda İngiliz tiyatrosunda bireyin içsel ya da psikolojik gerçekliğinin ön plana çıkarıldığını vurgulamakla beraber ilgili bölümde Sarah Kane'in 4:48 Psychosis (2000), Anthony Neilson'ın Realism (2006) ve The Wonderful World of Dissocia (2007) oyunları ile Ed Thomas'in Stone City Blue (2004) adlı oyunlarından örnekler göstererek yirmi birinci yüzyılda tiyatronun karakterlerin psikolojik gerçekliğini hayal, halüsinasyon ve fantezi düzleminde ele aldığının altını çizer. Ona göre, akıl sağlığından yoksun kişilerin iç dünyalarında yaşadıkları sorunlar tiyatroda psikolojik gerçekçilik ile yansıtılmıştır (s.195-200).

Aston ve Sierz'in yorumlarından da yola çıkarak psikolojik gerçekçiliğin yirminci yüzyıl tiyatrosunun önemli bir unsuru olduğunu söylemek mümkündür. Çünkü iki tiyatro araştırmacısının vurguladığı üzere çağdaş tiyatro, yaşadıkları travmatik olaylar neticesinde psikolojik sorunlarla boğuşan karakterlerin iç dünyalarını psikolojik bir gerçekçilikle çeşitli düzlemlerde sergilemeye yönelmiştir. Travmatik olayların sebebiyet verdiği ruhsal sancıları yaşayan karakterlerin zihinlerinin içindekiler, sahnede tüm çıplaklığıyla seyirciye iletilmiştir. İngiliz tiyatrosunda Sarah Kane (1971-1999), Terry Johnson (1955-), Sarah Daniels (1956-), Martin Crimp (1956-), Joe Penhall (1967-) ve Anthony Neilson (1967-) gibi isimler bu noktada öne çıkarlar. Her bir oyun yazarı yaşadıkları olaylardan dolayı ruhsal sıkıntılar çeken kişilerin iç çatışmalarını sahnede açığa çıkarıp bir tür akıl uzamı tiyatrosu veya psikolojik gerçekçi bir tiyatro üretmişlerdir. İnsan ruhunun denge ve dengesizlik arasındaki hassas durumunu oyunlarında sorgulamaya açan bu oyun yazarları; bir nevi sesi çıkmayan, ötelenip kenara itilen insanlara tiyatroda ses verip seyirciyi onların iç dünyalarına konuk etmişlerdir. Bu çalışma, tiyatro ve psikolojik gerçekçilik arasındaki ilişkiyi Solange Ayache’nin önerdiği 'Kafana Tiyatro' kavramı üzerinden İngiliz tiyatrosundan seçilen örneklerle açıklamayı amaçlamıştır.

\section{Tiyatro ve Psikolojik Gerçekçilik}

Analitik psikolojinin kurucusu olarak anılan İsviçreli psikolog Carl Jung, "İnsan ruhu (psyche) bütün bilimlerin ve sanatların kaynağıdır" (1981, s.53) der. Şüphesiz ki hem bilim hem sanat sürekli ilerleme peşinde koşan ve değişime açık insan ruhuna çok şey borçludur. İnsan ruhunun bilimin değerli bir kaynağı olmasına katkılar ise Avusturyalı psikolog Sigmund Freud'un ortaya attığı Psikanaliz kuramıyla olmuştur. İnsan ruhunu bilinç ve bilinçdışı olarak ayıran, bilinci buzdağının görünen yüzü ve bilinçdışını ise buzdağının görünmeyen yüzü olarak tarif eden Freud, insan ruhunu derinlemesine incelemiștir. Freud'un

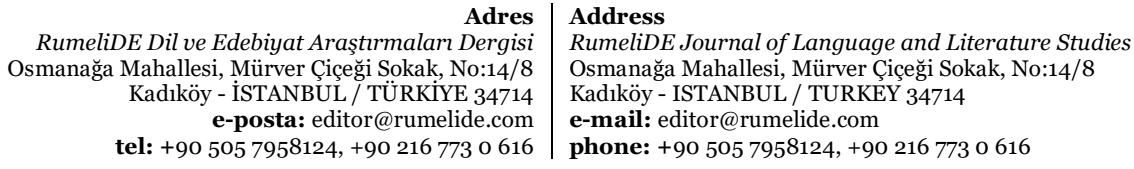


Psikanaliz kuramıyla ortaya attığı bilinçdışı ile ilgili gerçekler, sanatın birer malzemesidir. İki büyük dünya savaşının deneyimlendiği; kıyımların, ekonomik krizlerin yaşandığı ve bu gelişmelerin akabinde toplumsal değișmelerin ortaya çıktığı; genel bir ifadeyle travmaların olduğu bir yüzyıl olarak mimlenen yirminci yüzyıl özellikle sanatta ve edebiyatta insan psikolojisinin ön plana çıtığı bir döneme işaret eder. Çünkü savaş ve bunalımlar, yani insanlığın deneyimlendiği yıkıcı ve dönüştürücü güçler, onu bir yandan travmatik olaylarla başa çıkmaya yönlendirirken bir yandan da var oluşsal bir sorgulamaya itmiştir. Tanrı ile birlikte tüm insani değerlere şüpheyle bakma sonucunu doğuran bu durum, bir nevi eski dünya düzeninin yıkımı ve yeni dünya düzeninin yaratımı anlamına gelmektedir. Bir taraftan yaşanan yıkıcı olayların bir taraftan da modern bilimin öncülüğünde gelişen sanayileşmenin getirdiği yeni dünya düzeni ile insanın bireyselliği ön plana çıkmış ve artık dünyayı anlamsız ve korkunç bir yer olarak gören ve kendisini de bu anlamsız, korkunç ve saçma yerde değersiz hisseden insanın durumu için tiyatro da sessiz kalamayıp insanın içinde bulunduğu bu kaotik ortamı Absürd Tiyatro (Absürd Theatre), Kıyıcı Tiyatro (Theatre of Cruelty), Felaket Tiyatrosu (Theatre of Catastrophe) ve Suratına Tiyatro (In-Yer-Face Theatre) gibi çeşitli tiyatro hareketleriyle sahneye taşımıştır.

İngiliz yazar Sarah Grochala, Subjectivity on Stage (2015) başlıklı yazısında roman ve tiyatro türleri üzerinden, iki türün farklılıklarına da dikkat çekerek, psikolojik gerçekliğin nasıl sunulduğunu açıklar. Yazar, tiyatro türünün psikolojik gerçekçiliği ortaya koymasının birtakım zorlukları olduğunun ve öznelliğin sahnede yansıtılmasında farklı uygulamaların vuku bulduğunu belirtir. Ona göre, teorik açıdan öznel bir perspektiften oyun üretmek, imkânsız gibi gözükmektedir. Çünkü tiyatro, roman ile karşılaş̧ırıldığında, “'aracı iletişim sistemi' olmadığı için nesnel bir araç olarak düşünülmektedir" (Grochala, 2015). Ona göre, roman türü doğası gereği geleneksel olarak öznel bir perspektif önerebilir. Bir aracı olarak roman anlatıcısı okuruna kimi zaman karakterlerin yaşadıkları, tanık oldukları ya da duydukları geçmiş olaylar hakkında bir şeyler söyler; bunu yaparken ise ya doğrudan kimliğini okuruna gösterir ya da konuyla ilgili herhangi bir bilgi vermeyip sadece olayları okuruna aktarmakla yetinir. Anlatıcı, olaylar üzerine kimi zaman ise duygu ve düşüncelerini dile getirebilir. Bu noktada ise Grochala'ya göre, roman nesnel bir gerçekliği ifade etmenin ötesinde öznel bir gerçekliği açı̆̆a vurmuş olur. Buna karşın yazar, öznel anlatı biçiminin aslında Antik Yunan'dan bu yana dramanın temel anlatı biçimlerinden biri olduğunu iddia eder. Antik Yunan ve Roma oyunlarında haberci rolündeki kimselerin sahne üzerinde seyirciye öznel yargılarını, duygu ve düşüncelerini sunduklarını dile getirir.

Adı geçen çalışmasında Grochala, günümüz dramasında psikolojik gerçekçi anlatı yapısının, kendini farklı yollarla ortaya koyduğunu ifade eder. Groachala yazısında 'Postdramatik Tiyatro' kuramının mimarı Alman tiyatro araştırmacısı Hans-Thies Lehmann'ın yaptığı çağdaş tiyatronun eyleme karşıt olarak anlatıya yönelik bir eğilim gösterdiği vurgusunun altını çizer. Yani sahne üzerinde hikâyenin olayını görmek yerine seyirci, olan olayların karakterler tarafından anlatımına güvenmek zorunda bırakılmıştır. Örneğin, İngiliz oyun yazarı Simon Stephens'ın Pornography (2008) adlı oyununda dört karakter dramatik bir eylemi sahnelemek yerine anlatı yoluyla 7 Temmuz 2005 Londra saldırıları hakkında kişisel deneyimlerini ortaya koyar. İrlandalı oyun yazarı ve çevirmen Brian Friel'ın Faith Healer (1979) adlı oyununda üç farklı karakter aynı olayın farklı versiyonlarını seyirciye aktarır. İngiliz oyun yazarı Duncan Macmillan'ın People, Places and Things (2015) adlı oyununda olaylar doğrudan Emma'nın gözünden hem duygusal durumuna hem de uyuşturucu aldıktan sonraki hali göz önünde tutularak özel yargılar açığa vurulacak şekilde anlatılır. Amerikalı oyun yazarı Tennessee Williams'ın The Glass Menagerie (1944) adlı oyununda ise Tom'un kız kardeşi ve annesini terk etmesine neden olan olaylar, saatin tersi yönünde bir zamansallık takip edilerek Tom'un kişisel perspektifinden ortaya konulur. Bu örneklerden anlaşıldığı üzere, Grochala'ya göre, çağdaş tiyatroda olayların sahnede sergilenmesi yerine karakterlerin iç dünyalarında olaylara yönelttikleri bakış açılarının sergilenmesi söz konusudur. Çünkü çağdaş tiyatroda karakterler hikâyelerini anlatırken hem

\footnotetext{
\begin{tabular}{r|l} 
Adres & Address \\
RumeliDE Dil ve Edebiyat Araşttrmaları Dergisi & RumeliDE Journal of Language and Literature Studies
\end{tabular} Osmanağa Mahallesi, Mürver Çiçeği Sokkak, No:14/8 $\quad$ Osmanağa Mahallesi, Mürver Çiçeği Sokak, No:14/8 Kadıköy - ÍSTANBUL / TÜRKIYE 34714 Kadıköy - ISTANBUL / TURKEY 34714 e-posta: editor@rumelide.com e-mail: editor@rumelide.com tel: +90 505 7958124, +90 2167730616 phone: +90 505 7958124, +90 2167730616
} 
birer kahraman hem de birer yazar olarak var olurlar. Geçmiş olayları seyirciye iletirken bir taraftan olayların gerçek doğasını ortaya koyarlar bir taraftan da anlatıcının gerçek karakterini bilinemez bir hale sokarlar. Bu bağlamda ise seyirci sadece olayların anlatıcı tarafından kendisine sunulduğu kadarından haberdar olur ki bu olayların öznel bakış açılarıyla aktarıldığı için nesnel gerçekliğinden sıyrıldığı anlamını taşır. Yazar, son yıllarda İngiliz tiyatrosunda psikolojik gerçekçiliği ortaya koyan oyunların sayısının arttığının altını çizer. Bu durumun temel nedeni olarak ise hem kendimize hem de yaşadığımız dünyaya yönelttiğimiz bakış açısındaki değişiklikleri, yani postmodern yaşam gerçeğimizi gösterir:

\begin{abstract}
Postmodernist düşünce, dünyayla öznel bir bakış açısı dışında bir ilişsi kurmamızın imkânsız olduğunu iddia eder. Dünyayı sadece kendi deneyimlerimizin merceğinden görebiliriz. Herhangi bir olay dizisi için nesnel bir gerçek yoktur. Sadece onlara yönelttiğiniz bakıș açısı vardır. Bu bakıs açısı, kaçınılmaz olarak içinde yaşadığımız kültür ve dünyayla ilgili kişisel deneyimlerimiz tarafından şekillendirilir. Bir dizi olayın nesnel gerçeği, kavrayışımızın ötesindedir. Bu öznel oyunlarda, bu fikir, olayların yalnızca bir bireyin onlarla ilgili deneyimine dayanarak açıkça görüldüğü gerçeğinde yansitılır. Tiyatronun bize hem dünya hem de kendimiz hakkında nesnel evrensel gerçekler sunabileceği fikri, öznel biçimin bu kullanımıyla sorgulanir (2015).
\end{abstract}

Yazar, değişen dünya düzeninin bizi öznelliğe taşıdığını ve tiyatronun da bu öznelliği ortaya koymak üzere çeşitli stratejiler geliştirdiğini vurgular. Buna göre, postmodern dünya parçalanmış ve incinmiş bireyin öznelliğini, onun bireysel deneyimlerine dayanarak ve anlatı yapısını, kurguyu bozarak sahneye taşımakta ve seyircisini öznel gerçekliklerle yaşamı kavramaya yönlendirmektedir.

İnsan varlı̆̆ının pür dış gerçeklikten oluşmadığı içsel gerçekliğinin de ona olduğundan derin anlamlar kattığı düşüncesiyle İngiliz oyun yazarları tiyatro sahnesinde zihni yansıtmışlardır. Sorbonne Üniversitesi öğretim üyelerinden Solange Ayache 2017 yllında yaptığı "In-Yer-Head' Theatre: Staging the Mind in Contemporary British Drama Towards a Quantum Psychopoetics of the Stage" başlıklı doktora tez çalışmasında 2000'li yıllarda İngiliz tiyatrosunda karakterlerin içsel yaşamlarını merkezine koyarak seyirciyle bulușturan oyunları, Aleks Sierz'in 'Suratına Tiyatro' (In-Yer-Face Theatre) kavramına gönderme yaparak 'Kafana Tiyatro' (In-Yer-Head Theatre) veya "Akıl Uzamı Tiyatrosu' (Theatre of Mental Space) örnekleri olarak değerlendirir. Ayache'ın türettiği "Kafana Tiyatro" kavramı, tiyatro sahnesinde bireyin psikolojik karmaşıklığını, yaşadığı travmatik deneyimlerini, nevrozlarını ve psikolojik bozukluklarını sergileyen; bunu yaparken de sahne uzamını ve zamanını hayali olana dönüştüren bir tiyatro geleneğini; yani zihnin tiyarosunu tanımlar.

Ayache’a göre, yirminci yüzyllın önde gelen yazarlarından Martin Crimp, Sarah Kane, Caryl Churchill (1938), Helen Cooper (1947-), debbie tucker green, Michael Frayn (1933-), Simon Stephens (1971-), Nick Payne (1984-), Mark Haddon (1962-) ve Anthony Neilson gibi pek çok oyun yazarı son dönem oyunlarında karakterlerinin iç dünyalarını sahnede zihinsel mekânlar yaratarak sergilemiş ve böylelikle hem psikolojik gerçekçiliğin hem de sahne gerçekçiliğinin yeniden tanımlanmasını zorunlu kılmışlardır. Zihinsel mekânlarda geçen eserlerde, "öznenin spekülatif, kırınımlı ve çoğul varoluş biçimi” (Ayache, 2017) sahnede seyirciye gösterilmiştir. Ayache, kuantum teorisinden çift yarık deneyi (the double slit-experiment), dalgaparçacık ikiliği (the wave-particle duality), dalga fonksiyonunun çöküşü (the wavefunction collapse), gözlemci etkisi (the observer effect), kuantum uyumsuzluğu (quantum decoherence), üstdüşüm (superposition), dolanıklık (entanglement) ve çoklu-dünyalar kuramı (the many-worlds interpretation) gibi terimleri ödünç alarak önerdiği kavramı açıklamıştır. Ona göre, zihinsel mekânlarda geçen oyunlarda "aklımızın belirsizliği vurgula[n]mak" (2017) istenmiştir. 'Kafana Tiyatro' kavramı da "bilinçdışı komplekslerden, travmadan, psikozdan ya da beyin hastalığından etkilenen örselenmiş zihinlerin öznel gerçekliğini oluşturan bir dizi psikolojik savunma mekanizması, bilişsel çarpıtma ve psikiyatrik veya nörolojik semptomlar uyandır[an]" (2017) oyunları tarif eder. İnsan bilincinin ve bilinçdışının doğasını

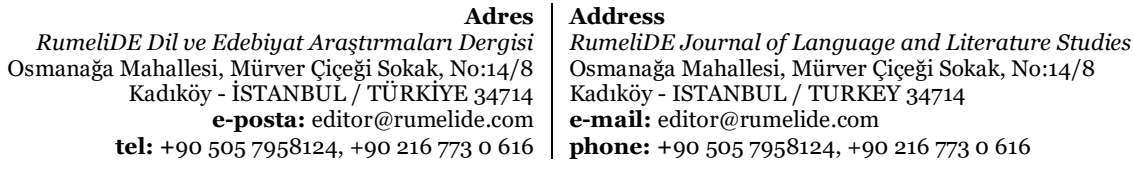


açığa vuran bu psikolojik gerçekçi oyunlar, tiyatronun nasıl insan zihninin keşfedilmemiş bölgelerini veya travmatik zihinleri ortaya koymaya yöneldiğini bize gösterir.

Ayache, kavramı ortaya atmasında çoğunlukla kadın karakterleri merkeze koyup onların örselenmiş zihinlerini sahneye taşıyan Sarah Kane'in 4.48 Psychosis adlı oyununun dönüm noktası olduğunu ve kavramın Kane'in 4.48 Psychosis, Neilson'ın The Wonderful World of Dissocia (2004), Ravenhill'in pool (no water) (2006) ve Ridley'in Dark Vanilla Jungle (2014) gibi eserler başta olmak üzere yirminci yüzyllın sonundan günümüze kadar yazılmış pek çok İngiliz oyununu da nitelendirdiğini belirtir. Bahsi geçen oyunlar, ona göre "bilinçdışının derinliklerine inen ve psikolojik kompleksleri ve travma sonrası zihin manzaralarını araştıran bu yeni dalgaya katkıda bulunmaktadır" (e-posta, 30.09.2018). Ayrıca psikolojik gerçekçilik doğrultusunda yazan oyun yazarlarından biri olarak karşımıza çıkan İngiliz oyun yazarı Martin Crimp (1956-) kendisine iki tür yazma biçimi geliştirdiğini, Attempts On Her Life (1997) ve Fewer Emergencies (2005) gibi oyunlarında içsel uzamı keşfetmeyi denediğini ve zihinsel bir uzamı sahneye taşıdığını söyler (2006). Crimp tıpkı Kane ve Neilson gibi tiyatronun mekân ve uzam konusunda fizikselin ötesine geçip zihinsel olana yönelerek yeni boyutlar kazanmasına katkı sunmuştur. Gerek Kane, Neilson ve Ravenhill gerekse Ridley ve Crimp söz konusu oyunlarında karakterlerinin iç dünyalarında yaşadıkları problemleri, travmatik geçmişlerini dramatikleştirerek sahnede ortaya dökmüşler ve adeta karakterlerin zihnini sahne üzerinde seyircisi için somutlaştırmışlardır.

\section{Tiyatro ve travma}

Post-travmatik kültür çalışmaları ile tanınan Kirby Farrell'in belirttiği üzere, yaşadığımız toplum travma toplumudur. Ona göre, "çağdaş kültürde (...) travma hem klinik bir sendrom hem de bir mecazdır (...) karmaşık, stresli bir toplumun tehdit edici bir şekilde kontrolden çıkmış gibi görünen bir dünyayı açılamak için kullandığı stratejik bir kurgudur" (1998, s.2.). İlk büyük travmasını daha doğarken yaşadığı düşünülen insan için travma çok da yabancı bir deneyim değildir. İlk büyük travmatik deneyiminden sonra yaşadığı dünyayı anlamlandırmak için bile insan, daha başka travmalar ile baş etmek zorunda kalmıştır. Yani dünya içinde karmaşık varlığını anlamlandırmaya çalışırken insanın travmatik bir durum olarak hem dünya hem insan gerçeğiyle mücadele içinde olması söz konusudur. Kendi için yarattığı kültür, inanç bile çoğu durumda onu yarı yolda bırakırken insan için en temel gereklilik ise travmatik durum karşısında ne olursa olsun sağlam durabilmesidir. Ancak insan için bu durum o kadar kolay olmayacaktır. Büyük bir dünyanın stresi ile başa çımak insan için epey yorucudur. Durumun farkında olan çeşitli bilim insanları için insanın içsel dünyası önemli bir meşguliyet konusu olmuştur. Özellikle on dokuzuncu yüzyıl son çeyreğine doğru çeşitli kuramcılar insanların ruh sağlıklarını etkileyen faktörleri ve insanların bu faktörlere verdikleri tepkileri araştırma konusu yapmışlar; bu da psikoloji biliminin gelişmesinde etkili olmuştur. Yirminci yüzyılda resmen tıp literatürüne giren travma ise araștırma konusu yapılan ve psikoloji biliminin gelişim katetmesinde ön plana çıkan konulardan biridir.

Travma kişinin ruhsal ve bedensel yaşantısına zarar veren, onu sarsan ya da inciten olayları adlandırmak için kullanılan bir kavramdır. Kavram, Eski Yunancada derinin bütünlüğünün bozulduğu her türlü yaralanma, yara anlamına gelen traûma ( $\tau \alpha \tilde{v} \mu \alpha)$ sözcügünden türemiştir (Goulston, 2011, s.22). Psikoloji literatürüne ilk olarak insan bütünlüğüne zarar veren her türlü fiziksel etkiyi tanımlayacak şekilde giren travma kavramının anlamı sonrasında ruhsal etkileri de kapsar şekilde genişlemiştir. Bu bağlamda ise Profesör Cathy Caruth'un Trauma: Explorations in Memory (1995) başlıklı çalışmasında yaptığı tanımlama öne çıkar. Buna göre, travma "deneyim sırasında veya sonrasında başlamış olabilecek uyuşukluk ile birlikte, bu olaydan kaynaklanan tekrarlayan, araya giren halüsinasyonlar, rüyalar, düşünceler veya davranışlar şeklini alan ve ayrıca olabildiğince olayı hatırlatan uyaranlara karşı uyarılmayı (ve bunlardan kaçınmayı)

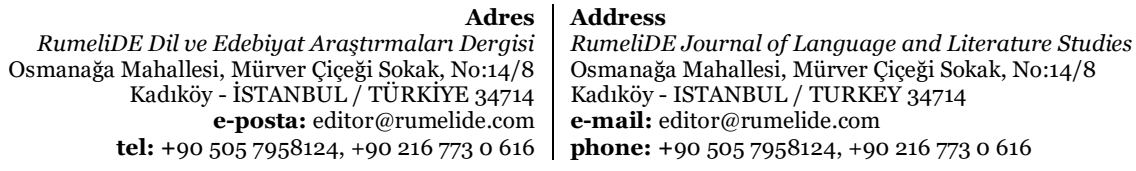


arttıran ezici bir olay veya olaylara, bazen gecikmiş bir yanıt”tır (1995, s.4). Caruth'un da belirttiği üzere travma, travmatik olayı deneyimlemenin ardından gelișen bir durumu ifade eder ki bu durum tam zamanlı olmaktan ziyade tekrarlama olarak ortaya çıkmakta ve bireyi etkisi veya kontrolü altına almaktadır.

Fiziksel, psikolojik ya da cinsel şiddet mağduru bireylerin her türden travmatik deneyimlerini anlatmaları ise özelikle travma çalışmalarının gelişmesinde önemli bir rol oynamıştır. Psikanaliz ve edebiyat ilişkisi üzerine çalışmalarıyla tanınan Shoshana Felman ve Dori Laub'un da vurguladıkları gibi, travmatik geçmişi olan bireyler, bu tatsız deneyimlerini anlatmaya ihtiyaç duymaktadırlar; çünkü sessiz kalmak onlar için yıkıcı bir süreç yaratabilmektedir. Travma geçmişi olan bireyler, başlarından geçenleri anlatarak kendilerini rahatsız eden şeylerle yüzleşebilmektedirler. Felman and Laub'un da belirttikleri üzere, travma hikâyelerinde "tanıklar uzun bir süredir bekledikleri birine konuşmaktadırlar" (1992, s.71-72). Bu şekilde bir yandan kendi hikâyelerine diğerlerini de ortak ederek onların kendileriyle empati kurmalarını sağlamakta bir yandan da kendilerini rahatlatmakta ve bir tür arınma yaşayabilmektedirler. Bu noktada edebiyat başta olmak üzere her türden anlatı, travmatik deneyimleri diğerlerine aktarmak için önemli bir araç olarak ortaya çıkar. Gizli kalmış olanı ortaya döken bu anlatılarda kişi, bir başkasının travmatik deneyimini deneyimleyebilmektedir. Bu alanda tiyatro, travmatik geçmişi yansıtan önemli ve dikkat çekici bir sanatsal etkinlik olarak karşımıza çıkar.

İlandalı performans ve kültür araştırmacısı Patrick Duggan, karşımıza sıklıkla çıkan travmanın, günümüzde ilettiği duygu ve anlamı yitirip sıradanlaştığını belirtir. Duggan, pek çok alanda çokça tartışma konusu yapılan travmanın son dönemlerde ise tiyatro çalışmalarında öne çıtığının altını çizer (2012, s.3). Trauma-Tragedy: Symptoms of Contemporary Performance (2012) başlıklı çalışmasında yazar, travma ve tiyatro arasındaki ilişkiyi inceleyip 'travma trajedisi' kavramını ortaya atar. Travma trajedisine örnek oyunları arasında ise Sarah Kane'in Blasted (1995), Kira O'Reilly'nin (1967-) Untitled (Syncrope, 2007) ve Nicholas Wright'ın (1940-) His Dark Materials (2003) adlı oyunlarını gösterir. Caruth'un yaptığı tanımlamadan da anlaşıldığı üzere bir tekrarlama şeklinde ortaya çıkan travma, trajedi gibi önceden meydana gelmiş bir olayın/eylemin taklididir ve bu noktada trajedi ile arasında yakın bir ilişki vardır (Levine, 2009, s.50). Duggan da ortaya attığı travma trajedisi kavramıyla bu yakınlığa işaret eder.

Duggan'a göre tiyatro, performans ve travma arasında eskiye dayalı bir ilişki söz konusudur: "Antik Yunanlılardan beri tiyatro, (özellikle klasik trajik biçimler aracilığıyla) travmanın temsili ve çözümlenmesiyle ilgilenmiş̧ir. Travma, seyirciyi tiyatro aksiyonuna bağlayan, onları performans olayının daha da derinlerine çeken çağrıştırıcı ve duygusal bir güçtür" (2007, s.44). Yazar, modern kuramcllar tarafından ortaya atılan modern travma teorilerinin performatif olarak düşünülebilecek anlatılarla dolu olduğunu belirtir (2012, s.4). Duggan, kitabında travmanın doğasını ise beden ve zihin arasındaki ikilik üzerinden açıklar. Travmanın orijinal an/travmatik olay (original moment/trauma event) ve yıkıcı geriye dönüş/travma belirtileri (disruptive return/trauma symptoms) olmak üzere iki safhada incelenebileceğini dile getiren araştırmacı, bedenin travmayı olay anında deneyimlerken zihnin sonrasında tekrar tekrar deneyimlediğini, yani kişi için travmanın tekrar eden, aniden gelen bir deneyim olduğunu ifade eder. Tiyatroda travmatik deneyimin ilk örneklerinin ise William Shakespeare'in Macbeth (1606) ve John Webster'ın The Duchess of Malfi (1614) oyunlarında görüldüğünü iddia eder (2012, s.23).

İngiliz yazar ve akademisyen Roger Luckhurst, insanlığın yaşadığı şok edici deneyimlerin ardından 1990'lardan sonra İngiliz toplumunda bir travma kültürünün etkili olduğunu belirtir (2008, s.2). Bu travma kültürü, dönem oyunlarında çokça kendini gösterir. Buna göre, oyun yazarları oyunlarında travmatik deneyimler yaşamış kişilerin iç dünyalarını seyircilerine yansıtmaya çalışmışlardır. Travmatik geçmişleri olan kişilerin hayat hikâyeleri seyirciyle buluşturularak seyircinin onlarla ortak bir deneyim içerisine

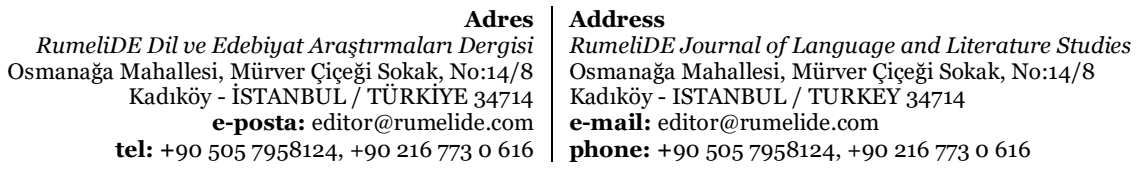


girmeleri sağlanmıștır. Bu noktada seyirci bir anlamda sahnede gördüklerine bir tanık misyonu yüklenmiş bir anlamda da karakterlere sempati duyarak ortak bir duygu paylaşımı yaşamıştır. İngiliz tiyatro geleneğinde özellikle Absürd Tiyatro ve Suratına Tiyatro ekollerinin sahne üzerinde insanın ya da insanlığın travmatik bilincini yansıtması bakımından bir farkındalık yarattı̆̆ı söylenebilir. Çünkü yaşamın dar kalıplarından çıkıp insan zihninin sınırsızlı̆̆ında dolanma imkânı sunan tiyatro, bu noktadan itibaren içsel gerçekliğin tiyatrosuna dönüşmüştür.

Savaş deneyimi ardından ortaya çıkan ve insan varlığını varoluş düzleminde sorgulayan Varoluşculuk akımının etkisiyle gelişen Absürd Tiyatro, saçma bir dünyada insanın sessiz çığlığını dikkate değer bir yankıyla duyurmayı başarmıştır. Onca kıyımın, yıkımın, zalimliğin türediği dünya saçmalığı içinde çaresiz bir konumda bulunan insanın iç dünyasını sahne, dil ve içerik düzleminde psikolojik bir gerçekçilikle yansıtmıştır. Retreats from Realism in Recent English Drama (1991) başlıklı çalışmasında Ruby Cohn, yeni yazımın geliştiği 1990'lı yıllarda saf gerçekçiliğin karşısında kirli bir gerçekçiliğin gelişme gösterdiğinin altını çizer. "Sosyal gerçekçi oyunların kalıbını kırma[yı]" (Daldry, 2007, s.8) hedefleyen yeni yazın içerinde gelişen, Alex Sierz'in deyiş̧iyle Suratına Tiyatro ekolü; saf dış gerçekçiliğe olan eğilimlerin gerilediğini, yeni bir bakış açısından gerçekçi anlatımın önem kazandığını müjdeler. Cohn'un deyimiyle bu gerçekçilik "giderek gerçeküstü, yıpranmış bir manzara ortaya çıkarmak için gerçekçiliğin güvenli ve tanıdık bir alanını resmen kırmıştır" (1991, s.21). Suratına Tiyatro; şiddet, kan, baskı ve savaş gibi unsurların ortasında kalan insanın travmatik zihnini kirli bir gerçekçilik ve sert bir üslûpla seyircisine yansıtmıştır. Sarah Kane, Anthony Neilson, Mark Ravenhill ve Philip Ridley gibi önemli isimlerin yer aldığı bu kuşak hem psikolojik olarak hem de fiziksel olarak acı çekmekte olan kişilerin iç dünyalarına seyirciyi konuk ederek onları bu kişilerin travmatik geçmişlerine tanıklık ettirmiş ve bu tanıklık süreci seyirci için de epeyce sarsıcı olmuştur.

İngiliz oyun yazarı Sarah Kane, Blasted (1995), Crave (1998) ve 4:48 Psychosis (2000) gibi önde gelen oyunlarıyla Suratına Tiyatro ekolünün öncüsü olarak kabul edilir. Anlatımı ve biçimsel teknikleriyle geleneksel gerçekçi anlatımı alaşağı eden Kane, yeni bir gerçekçi anlatı yapısı ortaya koymuştur. İnsan zihninin en derinlerine inerek gizli yanlarını, insanın karanlık dürtülerini sahnede tüm çıplaklığıyla ortaya dökmüştür. Kane'in savaş, aile içi şiddet, tecavüz ve fiziksel şiddet gibi travmatik deneyimlerini öne çıkardığı Blasted adlı oyununda seyirci travma deneyimi ile dolaylı bir yoldan yüzleştirilmiştir. Bosna Savaşı'nı (1992-1995) üzerinden savaş gibi travmatik bir deneyimi ortaya koyan oyun, sürekli şiddet üreten bir toplumda şiddetin ne kadar normalleştiğini göstermekle birlikte Ian'ın Cate'e tecavüz ettikten sonra Asker'in Ian'a tecavüz etmesi olayında olduğu gibi travmaların insan psikolojisini nasıl etkilediğini ve insan yaşamında nasıl kalıcı etkileri olabildiğini seyircisine göstermiştir. Duggan’a göre,

\begin{abstract}
Blasted, şiddet temsillerinin normalleştiği bir toplumda dikkati üzerine çekti, şiddeti ve travmayı İngiliz halkının görmezden gelebileceği bir yolda fazla "gerçek", fazla somut olarak sundu. (...) Blasted, dramatik bir şekilde hem aksiyonunda hem de dilinde seyircilerini ardı ardına korku ve travma görüntülerinin bombardımanına tutar, kelimenin tam anlamıyla onları sayısız travmatik olayla yüzleșmeye zorlar; oyun, kişilerarası ve içsel travmaların gücünü ve inceliklerini tasvir etme ve buna tanıklı etme girişimidir (2007, s.47).
\end{abstract}

Her ne kadar Blasted travmatik olayları seyircinin gözü önünde gerçekten sunmayıp karartma yoluyla onun hayal gücüne bırakacak biçimde sunmuş olsa da seyirci zihninde bir etki yaratmayı başarmıştır. Öyle ki bu etkiyi, Duggan "travma varlı̆̆ı etkisi" (2012, s.39) olarak tanımlar. Kane, seyircinin olaydan bir rahatsızlık duygusu hissederek ahlaki bir tepki almasına neden olan bir dürtü yaratmıştır. Performansın travmanın doğasını temsil etmede önemli olduğunu ve travmanın sahnede çeşitli araçlar ile seyirciyi olayın içerisine sokacak bir biçimde sahnelenebildiğini dile getiren Duggan'a göre, oyunun sahnelenmesinden sonra seyircide bıraktığı etki; tiyatro, performans ve travma arasındaki yakın ilişkiyi göstermesi açısından

Adres | Address

RumeliDE Dil ve Edebiyat Araştırmaları Dergisi $\quad$ RumeliDE Journal of Language and Literature Studies Osmanağa Mahallesi, Mürver Çiçeği Sokak, No:14/8 $\quad$ Osmanağa Mahallesi, Mürver Çiçeği Sokak, No:14/8 Kadıköy - ÍSTANBUL / TÜRKIYE 34714 Kadıköy - ISTANBUL / TURKEY 34714 e-posta: editor@rumelide.com e-mail: editor@rumelide.com tel: +90 505 7958124, +90 2167730616 phone: +90 505 7958124, +90 2167730616 
oldukça önemlidir. Fiziksel ve psikolojik travmayı ortaya koyan Kane, Blasted oyununda travmayı kurban açısından onun iç dünyasını sahnede ortaya koyacak şekilde temsil eder. İçimizde irkilme ve ürperme duygusu yaratarak bize "travmaya hitap eden çağdaş performansın belirli örneklerini görebileceğimiz, tanımlayabileceğimiz ve anlayabileceğimiz bir mercek" (akt. Micner, 2013) tutar. Bu noktada bu oyundan da örneklendiği üzere tiyatronun "katarsis, empati ve kolektif deneyim için bir forum" ve "deneyimlerimizin en iyisini ve en kötüsünü güvenli bir şekilde araştırdığımız bir alan” (Micner, 2013) yarattığı söylenebilir. Blasted oyununda olay dilin ötesine geçip performans ile hissedilebilir niteliğe büründürülmüş ve seyircinin travmatik olayı hissedip empati kurarak tepki vermeye yöneltilmesi söz konusu olmuştur. Bir diğer ifadeyle, oyunda travmanın etki boyutu seyircinin duruma tanık gösterilmesi ile genişletilmiştir (2007, s.55-56).

İngiliz yazar Christina Wald'ın da belirtiği gibi, travma "kişisel ya da kolektif tarihin telafisi mümkün olmayan, akıl almaz ve yetersiz kalan bölümünü belirleyen, modernizm ve genel olarak modernite için yeni bir yorum aracı" (2007, s.3) olarak karşımıza çıkar. 2010 yılında yayınladığı Hysteria, Trauma and Melancholia: Performative Maladies in Contemporary Anglophone Drama başlıklı çalışmasında Wald, histeri ve melankoli gibi travmanın tiyatroda 'performatif hastalıklar' (performative maladies) olarak nitelendirilebileceğini söyler ve bu üç kavramı "toplumsal cinsiyet kimliğinin performatif niteliğini temsil eden en belirgin metaforlar, metonimler ve mecazlar" (2007, s.5) olarak tarif eder. Bu tarifiyle Wald, tiyatroda travma, melankoli ve histerinin cinsiyet çalışmalarında ön plana çıkmış olduğunun altını çizmiş olur. Bu noktada Wald'ın ifade ettiği gibi, erkek karşısında duygusal yönden zayıf bir varlık olarak kabul edilen kadının histeri, travma ve melankoli konuları başta olmak üzere iç dünyalarındaki karmaşıklıkların sahnede temsil edilmesi, tiyatronun kadının içsel gerçekliğini ortaya koymaya yöneldiğini ifade eder. Bir anlamda tiyatro, "kadın bakış açısıyla güven ve huzursuzluk yapıları ve koşulları hakkında bilgi vermek" (Pewny, 2003, s.4) için kullanılmaktadır. Wald bu bağlamda ise kitabında Victoria Hardie'nin Sleeping Nightie (1989), Sarah Daniels'in Beside Herself (1990), Phyllis Nagy'nin Butterfly Kiss (1994) ve Claire Dowie'nin Easy Access (for the Boys) (1998) adlı oyunlarını örnek olarak gösterir. Cinsel istismar mağduru kadın karakterlere yer veren bahsi geçen oyunlar, travma geçmişi olan kadın karakterlerin iç dünyalarını cinsiyet meselelerini tartışmaya açacak şekilde sahneye taşımıştır.

İngiliz oyun yazarı Sarah Daniels, oyunlarında cinsel istismar üzerinden travma konusuna eğilir. Derin araştırmalar ardından yazılan Ripen Our Darkness (1982), Madness of Esme and Shaz (1988) ve Beside Herself (1990) adlı oyunlarında yazar, feminist bir bakış açısından kadın ve akıl sağlığı konusunu irdeler. Daniels, bu oyunlarında kadına yüklenen histeri ya da deliliğin ataerkil sistemin kadını kontrol edebilmek adına geliştirdiği bir sömürü aracı olduğunu vurgulamanın yanı sıra kadınları birbirleri ile dayanışma içinde olmaya davet eder. Beside Herself adlı oyununda babasının çocuk yaşta cinsel istismarına maruz kalan Evelyn adlı karaktere travmatik geçmişinin somut ifadesi olarak oyun boyunca Evelyn ve seyirci dışında hiç kimsenin görmediği Eve adlı hayali karakter eşlik eder. Hayali bir karakter üzerinden tiyatroda travmayı gösteren Daniels, Eve karakteriyle Evelyn'in kafasının içindekileri sahneye yansıtır. Böylelikle travmatik deneyimin etkisiyle çift kişilik sergileyen Evelyn'in iç dünyası hem karakter temsili hem de eş zamanlı sunum, yani zamansal-uzamsal boyutu etkileyen bir dramatik biçim ile ortaya konmuş olur ki bu Daniels'ın tiyatrosundaki deneyselliği de bizlere gösterir (Wald, s. 216). Düşmekten çok enkaza gömülmekten korkan (Daniels, s.187) ve babasının kendisine karşı işlediği suçtan dolayı kendini cezalandıran Evelyn, babasının işlediği suçu seyirci karşısında babayı suçlayarak itiraf etmesiyle suçlu zihinden kurtulur ve bu aynı zamanda da hayali karakterden kurtulması anlamını taşır. Daniels, cinsel istismar gibi travmatik olayı sahnede temsil ederken tiyatroyu kadına yönelik onur kırıcı bir erkek davranışı olan tecavüz ve toplumsal cinsiyet eşitsizliği gibi sosyal konuların ortaya döküldüğü, tartışıldığı bir platforma dönüștürmüștür. Travmayı hem hikâye edilebilir hem de hikâye edilemez olanı estetik bir düzeyde temsil ederek sergileyen yazar, oyunda 'travmatize bir gerçekçiliği' (traumatized realism), yani iç kurguyu ortaya dökerken anlatı

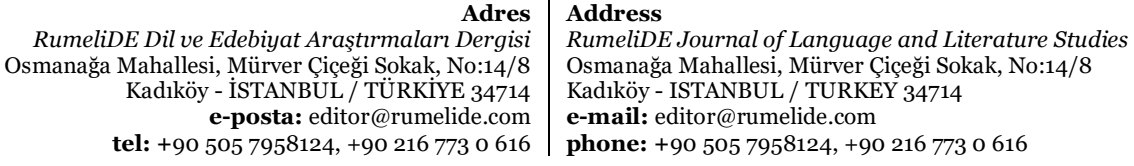


zamanını ve mekânını da farklı bir boyuta taşıyarak anlatıyı kesinlik, tutarlılık ve bütünlükten uzaklaştırır. Wald'a göre, oyun gerçekçi bir kurgu etrafında ilerliyor gözükürken aslında travmanın psişik geri dönüşlerini sahneleyerek dış gerçekliğinin yerine kahramanın içsel gerçekliği ayrıcalıklı bir konuma getirmiş ve böylece sahne gerçekçiliğinin geleneklerinden de uzaklaşmıștır. Ancak bu durum sahne gerçekçiliğinin terk edilmesi anlamına gelmez, bunun yerine sahne gerçekliğinin yeniden düzenlenmesi anlamını taşır (s.156-157). Wald'a göre, burada "psikolojik gerçekçiliğin radikal kullanımı ya da belki daha da uygun bir şekilde psikopatolojik gerçekçilik" (psychopathological realism) (s. 158) varlık göstermektedir. Daniels travmatik geçmişi olan bir kadının acı çeken ruhunu sahnesine taşırken bir taraftan seyirciyi travmatik karakter yoluyla travmanın bireysel boyutuna şahit eder bir taraftan da olayı kamusal alana taşıyarak cinsel istismarı gündeme getirip politik bir tutum da sergiler.

Fransız düşünür ve edebiyat eleştirmeni Michel Foucault'nun belirttiği gibi, "delilik hakikat ve dünyadan çok, insanın algılayabildiği kendi gerçeğiyle ilgilidir" (2015, s.55-56). İnsanın iç gerçeğiyle alakalı olan delilik, travmatik bir olayın sonucu vuku bulabilmektedir. Tiyatroda da delilik olgusu üzerinden psikolojik gerçekçilik temsil edilmektedir. Nitekim delilik, Amihud Gilead'ın belirttiği üzere, "rüyalar ve bilinçaltının yaptığı gibi içsel öznel gerçekliğimize aittir" (1999, s.33). Öncelikle delilik konusunun Antik çağdan bu yana farklı vurgulamalar ile tiyatro oyunlarında yer aldığını belirtmek gerekir. Delilik konusu üzerine ciddi çalışmalar yapan Amerikalı yazar ve akademisyen Lillian Feder Madness in Literature (1980) başlıklı çalışması, deliliğin Batı edebiyatının başlangıcından bu yana edebiyatın konusu olduğunu vurgulayarak başlar. Ona göre, "mevcut en eski mitlerden en güncel itiraflara, kurgulara, şiire ve drama kadar, delilik tasvirleri sembolik biçimde insanların kendi işleyişleriyle ve muazzam psişik deneyimleriyle meşguliyetlerini aktarır" (2020, s.4). Kitabında dengesiz zihnin edebi temsillerinin izini süren Feder, "nadiren görsel özellikler gösterdiği için başkalarının görmesi zor olabilen bir hastalık şekli" (2020, s.5) olduğundan bahsederek deliliğin içsel gerçekliğine vurgu yapar. Feder deliliği, "bilinçsiz süreçlerin onları kontrol ettikleri ve deneyime ilişkin algıları ve tepkileri belirledikleri ölçüde bilinçli olanlara baskın olduğu, geçerli mantıksal düşünce ve ilgili duygu standartlarına göre yargılandığında ise karışık ve uygunsuz olduğu bir durum" (2020, s.5) olarak tanımlar.

Antik dönem insanının gözünden kutsal bir ceza, bir intikam veya başarısızlıktan kaynaklanan bir musibet olarak değerlendirilen; Hristiyanlı̆̆ın baskın olduğu Orta Çağ döneminde şeytani bir olgu olarak görülen; Rönesans döneminde ahlaki bir hastalık olarak damgalanan; Neo-klâsik dönemde bir tutku olarak gösterilen; Romantiklerle birlikte duygusallıkla birleșip doğal ve yaratıcı bir dürtü olarak gündeme gelen ve gerçekçilerle beraber mekanik sosyal çevrenin etkisiyle insanın derinlerindekini göstermeye yönelik bir eğilim olarak belirtilen delilik; Antik dönemden hemen hemen modern döneme değin dışarıdan, yani nesnel bir bakış açısıyla ele alınmıştır. Tiyatroda delilik olgusunun temsili Shakespeare'in Hamlet (1603) ve Macbeth (1606) oyunlarından Thomas Dekker'ın The Honest Whore (1604) oyununa, John Fletcher'ın The Pilgrim (1647) oyunundan Georg Büchner'in Woyzeck (1835) oyununa, August Strindberg'in Father (1887) oyunundan Luigi Pirandello'nun Henry IV (1922) oyununa, Bertold Brecht'in The Good Person of Szechuan (1943) oyunundan Albert Camus'nin Calligula (1945) oyununa, Friedrich Dürrenmatt'ın, Physicists (1962) oyunundan Peter Weiss'in Marat-Sade (1963) oyununa, Peter Barnes'in The Ruling Class (1969) oyunundan David Storey'in Home (1970) oyununa, Wole Soyinka'nın Madness and Specialists (1970) oyunundan Peter Shaffer'ın Equus (1973) ve Pavel Kohout'un Poor Murder (1976) oyunlarına kadar bir çeşitlilik göstermektedir. Bu yazarların hemen hemen hepsi sahnede deneyimsel olarak deliliği yansıtmışlardır. Oyunlarda kimi zaman içsel gerçeklik rüya, hayal ve halüsinasyon düzleminde seyirciyle bulușturulmuştur. Çağdaş dönemde bir anlamda deliliğin dış gerçeklikten ibaret olmadığı ve içsel sürecinin de yansıtılması gerektiğine olan inancın da etkisiyle deliliğin öznel temsillerine yer verilmiştir. Bu bağlamda ise halüsinasyonlar önemli bir rol yüklenip tiyatronun 'varsanısal bir gerçekçilik' (hallucinated realism)

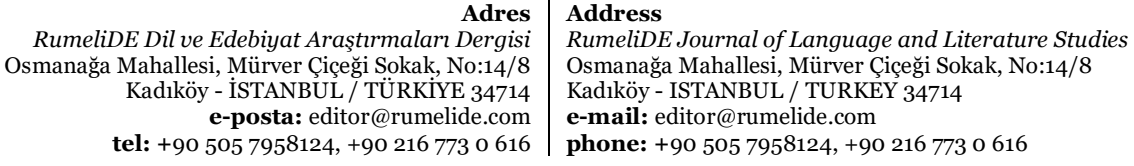


sunması mümkün kılınmıştır. Çünkü halüsinasyonlar bizi maddi dünyanın ötesinde bazı şeyleri deneyimlememizi ve bazı duygular hissetmemizi sağlamakta, bizi gerçeğin ötesinde hayallerle buluşturmaktadır. "Nesnel gerçeklikle çelişen düşüncenin düzensiz biçimleri" (Wald, 2012, s. 116) olarak ortaya çıkan halüsinasyonlar, duyu organlarının gerçekte var olmayan algılamalarıdır ve özü gereği karakterlerin iç dünyalarında hissettikleri duygu durumlarını somutlaştırarak görünür kılarlar.

Delilik konusu edebi, sanatsal ve kültürel çalışmalarda özellikle kadın ile ilintili olarak ele alınmıştır. On dokuzuncu yüzyıl tiyatrosunda akıl hastası kadın kahramanların çoğunlukta olduğu görülür. Histeri, delilik gibi akıl hastalıklarının çoğunu kadın ile özdeşleştiren ataerkil söylem/yazın bunun temel nedenini kadının aklı ile hareket edemeyen duygusal, naif ve hassas bir varlık olmasında yattığını vurgular. Peter Kurten adındaki bir adamın yaşadığı travmatik çocukluğun etkisiyle bir seri katile dönüşümünü anlatan Normal (1991) ve travma geçirmiş bir askerin eve dönüşünü ele alan Penetrator (1993) adlı oyunlarıyla bilinen İngiliz oyun yazarı Anthony Neilson, çağdaş İngiliz tiyatrosunun önemli seslerinden biri olarak onaylanmasını sağlayan "ilk kendinden etiketli psiko-absürd" (Sydney Theatre Company, 2011) oyunu The Wonderful World of Dissocia'da (2007) kadın ve delilik konusu üzerinden sahnede psikolojik gerçekçilik sergilemiştir. Oyunun başlı̆ı, "akıl hastalığının sonucu olarak gerçeklikten ayrılan insanları tanımlamak için kullanılan tıbbi terim" (Serjent, 2015) dissosiyatif bozukluk ile alakalıdır. İki perdeden oluşan oyun, ilk perdesinde Lisa'nın ilaçlarını almamasının da etkisiyle hastalığından dolayı gittiği fantastik bir dünyayı seyircisine tanıtmıştır ve bu noktada oyunun ilk perdesinde delilik konusu içsel bir gerçeklik olarak sunulmaktadır. İkinci perdede ise seyirci Lisa'yı bir akıl hastanesinin soğuk odasında acı ile kıvranırken bulur, bu durum açıkça deliliğin dış bir gerçeklik olarak temsilidir. Dan Rebellato'ya göre, ilk perde "travmatik bir bölüm" (2014) olarak karşımıza çıkar. Chris Wilkinson’a göre ise, "bu rahat dünya göründüğü gibi değildir ve yakında bölümün kişisel trajediyle parçalandığını keşfederiz” (2007). Aslında, bu Lisa'nın trajedisidir. İlk perdede meydana gelen olayların gerçek dünya ile hiçbir alakası yoktur. Yani Lisa, Alis'in Harikalar Diyarı'ndaki gibi mantıktan ve dış gerçeklikten sıyrılıp kendini hayal dünyasına bırakmıştır. Onun gerçekliğinin dış dünyayla herhangi bir mantıki dayanağı bulunmamaktadır. Seyirci yalnızca Lisa'nın zihnine konuk olmuş; sembolik bir anlatımla Lisa'nın psikolojik problemleri ile karşılaşmaktadır. Neilson, Dissocia oyununda müzik, dans ve pantomim gibi çeşitli tiyatral unsurları kullanarak tiyatroyu bir karnaval alanına çevirip travma geçirmiş bir zihni sahneye koymaktadır. Bir diğer ifadeyle Dissocia, "zihnin hareket ettiği yolu bir şekilde hareket ettiren bir yazma yolu bulma girişimi"dir (2007). Neilson, ilk perdede hayvanların konuştuğu, uçan arabaların olduğu, gerçek ve gerçeküstünün birbirine karıştığı bir fantastik dünya çizer. Yazar hem Realism (2006) hem de The Wonderful World of Dissocia oyununu kastederek oyun üretirken "insanların katılımını ve kahramanın psikolojik alanına girmesini sağlayacak bir biçim bulmak" (2008) amacında olduğunu belirtir ve tiyatrosunda psikolojik gerçekçilikle ilgilendiğini ifade eder. Dissocia'da seyirci oyun boyunca Lisa'nın kişisel yaşamıyla karşılaşıp zihninin en derinlerine inme olanağı bulur ve adeta "Lisa'nın psikolojik cehennemi"ne (Biçer, 2018, s.31) konuk olur. Oyununu üretirken insanın iç yaşamını keşfetmeye niyetlenen Neilson, Dissocia'da sahnede temsil ettiği şiddet, eğlence, neşe, korku ve üzüntü ile dolu insan gerçekliğiyle psikolojik bir karmaşıklığı, zihinsel bir çöküşü ortaya koymuştur.

\section{Sonuç}

Tiyatro, insan ruhunun derinliklerine inebilmeyi başarabilen bir sanat dalıdır. Öyle ki tiyatronun seyirci ile ortak bir alanda yüz yüze gerçekleștiriliyor olması, bu derinliği daha gerçekçi ve daha tinsel olarak yansıtmasını olanaklı kılar. Tiyatro, bilinçaltının en derinlerine inip oradaki karmaşıklığı, gizemi veya yaratıcılığı açığa vurabilen bir sanattır. Aristoteles'in Poetika'sında da belirttiği üzere daha ilkel çağlarda bir mimesis/taklit sanatı olarak gelişen tiyatro; bugün dans, müzik ve her türlü performans unsurunu çokça kullanarak insanın psikolojik gerçekliğini ortaya dökebilen oldukça interaktif bir sanat haline gelmiştir. Bu

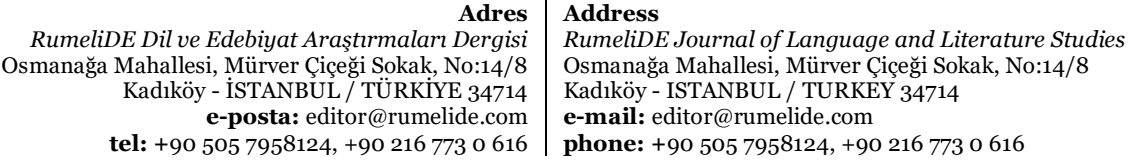


interaktif sanat, travma gibi geniş kapsamlı ve karmaşık bir konuyu insanları sarsacak bir biçimde sergilenmeyi de başarmıştır. Her türlü travmatik deneyim iç monolog, akıl uzamının temsil edilmesi, hayali karakterler ve gerçeküstü temsiller gibi çeşitli stratejilere başvurularak sahnede ortaya konulmuş ve seyirci bu travmatik deneyime ortak edilmiştir. Tiyatro, travmatik geçmişleri olan karakterleri sahnede görünür kılarak hem onların travmalarına neden olan savaş, tecavüz, cinsel istismar ve delilik gibi konuları irdelemiş hem de kısık seslilerin veya sesleri kısılmış olanların sesi olmayı başarmıştır. Tiyatronun travma başta olmak üzere her türlü toplumsal ve kültürel sorunu gündemine alıp tartışmaya açması ise onun ne kadar insan gerçeğiyle iç içe olan bir sanat olduğunu gösterir.

Özü itibariyle tiyatro çeşitli yönleriyle insanı yansıtmakta; onun dünyasını hem dış gerçekliği hem de içsel boyutuyla ortaya koymaktadır. İnsan ruhunun en gizli kalmış bölgesindeki korkularını, endişelerini, umutsuzluklarını, travmatik geçmişlerini, yalnızlıklarını ve hayal kırıklıklarını ele alan çağdaş tiyatro, Solange Ayache'ın isimlendirdiği șekliyle "Kafana Tiyatro", travma temelli tatsız anlatılarla doludur. Çağdaş tiyatroda insanın iç gerçekliği merkeze yerleştirilerek psikolojik bir gerçekçilik sunulmaktadır. Bunun en başarılı örneklerinden birini İngiliz tiyatrosunda "sahnenin kötü kızı" (Aston, 1995, s.79) olarak tanımlanan Sarah Kane vermiştir. Dünya gerçeğiyle yüzleşirken yaşadığı travmaların etkisiyle genç yaşta intihar eden Kane, Blasted adlı oyununda savaş, tecavüz, öfke ve şiddet yüklü dünyanın insanda yarattı̆̆ travmayı sorunsallaştırmıştır. Bosna Savaşı üzerinden savaş gibi travmatik bir olayı merkeze koyan ve travmatik ilişkilerin doğasını irdeleyen Kane, karakterlerini psikolojik bir gerçekçilikle sahneye taşımıștır. "Ana akım haline gelmiş tek radikal lezbiyen feminist" (Bloomsbury Theatre Guide, 1988, s.71) olarak nitelendirilen Sarah Daniels da tiyatrosunda kadın, delilik ve cinsel istismar üzerinden travma konusuna eğilmiștir. Kadın ve delilik üzerine yazdığı üçlemenin ilk kitabı olan Beside Herself adlı oyununda küçük yaşta babasının cinsel istismarına maruza kalan Evelyn isimli bir kadının travmatik zihnini geçmişi ve şimdisiyle birlikte Eve adlı hayali bir karakter yoluyla temsil etmiştir. Travmatik olayın etkisiyle kendisini suçlu hisseden Evelyn, gerçek suçlu babasının suçunu yüzüne vurmasıyla hem Eve adlı hayali karakterden kurtulmuş hem de travmasıyla yüzleşip bir arınma yaşamıştır. Oyun, kadın üzerinden sunulan histeri ve delilik kavramları çerçevesinde travmayı ele alıp psikolojik bir gerçekçilik ortaya koymuştur. "Suratına Tiyatro'nun kötü çocuğu" (Sierz, 2010) olarak anılan Anthony Neilson da travmayı kadın ve delilik üzerinden tartışmıştır. Tiyatrosunda psikoloji ve absürdizmi bir arada kullanarak psiko-absürd bir gelenek oluşturan Neilson, The Wonderful World of Dissocia adlı oyununda dissosiyatif bozukluk olarak adlandırılan bir akıl hastalığıyla boğuşan Lisa isimli karakter üzerinden travmayı hem yarattığı Dissocia adlı fantastik dünya yoluyla iç bir gerçeklik olarak hem de Lisa'nın akıl hastanesindeki durumunu gözler önüne sererek dış bir gerçeklik olarak sunmuştur. Gerek Sarah Kane gerek Sarah Daniels gerekse de Anthony Neilson tiyatrosunda travma temelli bu tatsız anlatıların örneklerini başarılı bir şekilde sunmuştur. Her bir yazar, başlarından geçen travmatik olaylar yüzünden ruhsal sorunlarla karşılaşmış karakterlerin iç dünyasını geleneksel gerçekliğin kalıplarını kırarak sahnede seyircisine aktarmış ve onları bir tür psikolojik gerçekçilikle buluşturmuştur. Sonuç itibariyle psikolojik gerçekçilik bugün yönünü performansa çeviren tiyatronun temel malzemelerinden biridir. Görünen o ki yaşadığımız postmodern toplumda yarasını tek başına sarmayı başaramayan insanın psikolojik gerçekliği daha farklı stratejilerle tiyatronun konusu olmaya devam edecektir.

\section{Kaynakça}

Aston, E. (2016). "Room For Realism". Twenty-First Century Drama: What Happens Now. Sian Adisseshieh \& Louise Lepage (ed.). Macmillan: Palgrave.

Aston, E. (1995). Introduction to Feminism and Theatre. London \& New York: Routledge.

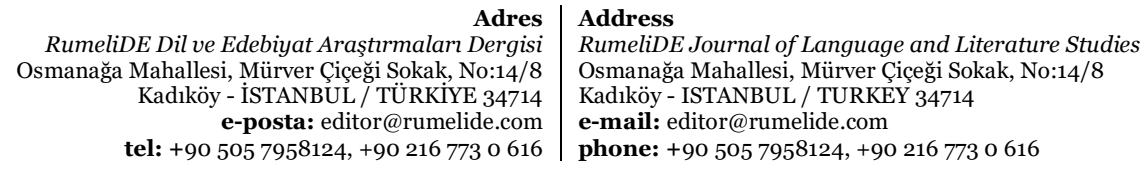

RumeliDE Dil ve Edebiyat Araştırmaları Dergis tel: +90 505 7958124, +902167730616 
Ayache, S. (2017). 'In-Yer-Head' Theatre: Staging the Mind in Contemporary British Drama Towards a Quantum Psychopoetics of the Stage. Doctorate Dissertation, Paris: Sorborne University.

Ayache, S. (2018, September 30). e-posta. Sorborne University, solange.ayache@gmail.com

Ayata, Y. \& Necati Tonga. (2008). “Psikolojik Roman, Romana Yansıyan Yazar ve Türk Edebiyatındaki Bazı Örnekleri Üzerine Bir İnceleme”. İlmî Araştırmalar, 25. http://turkoloji.cu.edu.tr/YENI\%20TURK\%20EDEBIYATI/Yunus\%20AYATANecati\%20TONGA.pdf, ss. 7-20. erişim tarihi: 22.10.2018.

Aytaç, G. (1999). Genel Edebiyat Bilimi. Ankara: Gündoğan Yayınları.

Biçer, A. G. (2018). "The Experiential Theatre of Anthony Neilson and The Wonderful World of Dissocia". Selçuk Üniversitesi Edebiyat Fakültesi Dergisi. (40). ss. 23-32.

Bloomsbury Theatre Guide. (1988). London: Bloomsbury.

Borgstrom, H. (1998). Performing Madness: The Representation of Insanity In $19^{\text {th }}$ And 20th Century Theatre, From Jean-Martin Charcot to Marguerite Duras. Doctor of Philosophy, Maddison: The University of Wisconsin.

Caruth, C. (1995). "Trauma and Experience: Introduction". Trauma: Explorations in Memory. Baltimore: Johns Hopkins University Press.

Cohn, R. (1991). Realism in Recent English Drama. Cambridge \& New York: Cambridge University Press.

Crimp, M. (2006). Into The Little Hill. https://www.ensemble-modern.com/en/mediatheque/texts/200610-01/into-the-little-hill-a-work-for-stage-by-george-benjamin-and-martin-crimp, erişim tarihi: 23.10.2018.

Cuddon, J. A. (1991). A Dictionary of Literary Terms. Cambridge, MA: Blackwell, 1991) ss. 771- 776.

Daldry, S. (2007). British Theatre of the 1990s Interviews with Directors, Playwrights. Mireia Aragay, Hildegard Klein, Enric Monforte \& Pilar Zozayapp. Houndmills, Basingstoke \& Hampshire: Palgrave Macmillan. ss. 3-14.

Daniels, S. (2013). Plays 2. London: Bloomsbury.

Duggan, P. (2012). Trauma-Tragedy: Symptoms of Contemporary Performance. Manchester: Manchester University Press.

Duggan, P. (2007). “Feeling Performance, Remembering Trauma”. Platform. 2(2).

Farrell, K. (1998). Post-traumatic Culture: Injury and Interpretation in the Nineties. Baltimore \& London: The Johns Hopkins University Press. 1998.

Feder, L. (2020). Madness in Literature. Princetown: Princetown University Press.

Felman, S. \& D. Laub. (1992). Testimony: Crises of Witnessing in Literature, Psychoanalysis and History. London \& New York: Routledge.

Foucault, M. (2015). Deliliğin Tarihi. M. A. Kılıçbay (çev.). Ankara: İmge Kitabevi.

Gilead, A. (1999). Saving Possibilities: A Study in Philosophical Psychology. Amsterdam \& Atlanta: Rodopi.

Goulston, M. (2011). Post-Traumatic Stress Disorder for Dummies. Hoboken: Wiley Publishing.

Grochala, S. (2015, November 4). "Subjectivity on Stage". Headlong. https://headlong.co.uk/ideas/subjectivity-stage/, erişim tarihi: 22.06.2021.

Jung, C. (1981). "Psikoloji ve Edebiyat”. Psikanaliz açısından Edebiyat. Selahattin Hilav (çev.). Ankara: Dost Kitabevi.

Kennedy, P. (2019). "Characters' Motivations and Thoughts in Psychological Realism". ThoughtCo. https://www.thoughtco.com/psychological-realism-2207838, erişim tarihi: 21.06.2021.

Levine, S. K. (2009). Trauma, Tragedy and Therapy. London: Kingsley Publishers.

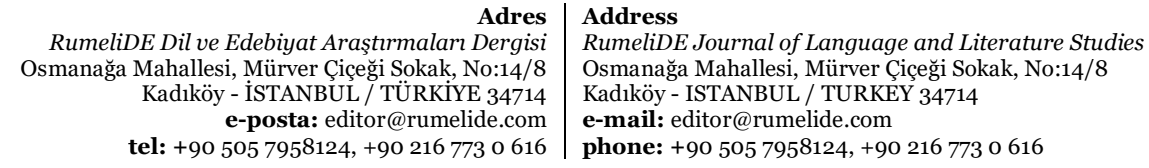


Long, H. \& R. J. So. (2016). “Turbulent Flow: A Computational Model of World Literature”. Modern Language Quarterly. 77(3). ss. 345-367.

Luckhurst, R. (2008). The Trauma Question, London \& New York: Routledge, 2008.

Micner, T. (2013). Book review: Trauma Tragedy Symptoms of Contemporary Performance. http://eprints.lse.ac.uk/52982/1/blogs\%20lse\%20ac\%20uk-

Book_Review_TraumaTragedy_Symptoms_of_Contemporary_Performance.pdf, erişim tarihi: 21.10.2018.

Neilson, A. (2007). "Foreword”. The Wonderful World of Dissocia \& Realism. London: Methuen.

Neilson, A. (2008). Plays 2. London: Bloomsbury Publishing.

Pewny, K. (2003). "Posttraumatic Theater. A Concept in Progress on the Performativity of Un/Rest". IWM Junior Visiting Fellows' Conferences. XV.

Ross, R. (2003). The Continuum Encyclopedia of American Literature. Steven R. Serafin \& Alfred Bendixen, (ed.). New York \& London: Continuum. ss. 935-939.

Rebellato, D. (2014, July). "Keeping It Real: Stories and The Telling of Stories at The Royal Court". Contemporary Theatre. https://www.contemporarytheatrereview.org/ 2014/keeping-it-real-royalcourt/. erişim tarihi: 26.10.2018.

Sydney Theatre Company. (2011, June 1). "In-Yer-Face”. https://www.sydneytheatre.com.au/magazine/posts/2011/june/feature-in-yer-face, erişim tarihi: 26.10.2018.

Serjent, C. (2015, November 7). “Dissocia”. Nerve.

Sierz, A. (2010, February 16). "New Writing in British Theatre Today", New Writing, Playwritings, Transcripts, http://www.theatrevoice.com/audio/new-writing-in-british-theatre-today/, erişim tarihi: 28.05.2020.

Sierz, A. (2011). Rewriting the Nation: British Theatre Today. London: Methuen Drama.

Wald, C. (2007). Hysteria, Trauma and Melancholia Performative Maladies in Contemporary Anglophone Drama. Houndmills, Basingstoke \& Hampshire: Palgrave Macmillan.

Wellek, R. (2005). “Edebiyat Tarihinde Realizm Kavramı”. Sıddık Yüksel (çev.). Din Bilimleri Akademik Araştırma Dergisi. 2. ss. 305-328.

Wilkinson, C. (2007, March 25). “An Outcast's Eye on Inner Life". Financial Times, https://www.ft.com/content/d9c4990e-d962-11db-9b4a-000b5df10621, erişim tarihi: 20.05.2020.

Adres
RumeliDE Dil ve Edebiyat Araştırmaları Dergis Osmanağa Mahallesi, Mürver Çiçeği Sokak, No:14/8 Kadıköy - İSTANBUL / TÜRKIYE 34714 e-posta: editor@rumelide.com tel: +90 $5057958124,+902167730616$
Address

RumeliDE Journal of Language and Literature Studies Osmanağa Mahallesi, Mürver Çiçeği Sokak, No:14/8

Kadıköy - ISTANBUL / TURKEY 34714

e-mail: editor@rumelide.com

phone: +90 5057958124, +90 2167730616 